Review Article

\title{
Clinicopathological Significance of Heat Shock Protein (HSP) 27 Expression in Gastric Cancer: A Updated Meta-Analysis
}

\author{
Tong Liu (D), Duo Liu, Xiangxue Kong, and Mei Dong $\mathbb{D}$ \\ Harbin Medical University Cancer Hospital, Harbin, China \\ Correspondence should be addressed to Mei Dong; 494731096@qq.com
}

Received 11 November 2019; Accepted 1 July 2020; Published 22 July 2020

Academic Editor: Massimo Nabissi

Copyright (C) 2020 Tong Liu et al. This is an open access article distributed under the Creative Commons Attribution License, which permits unrestricted use, distribution, and reproduction in any medium, provided the original work is properly cited.

\begin{abstract}
Aim. HSP27 is a protein chaperone protecting cell from heat shock, and upregulated HSP27 expression has been found in many different cancers. We conduct this update meta-analysis to evaluate the relationship between HSP27 expression and clinicopathological features. Methods. We searched PubMed, Chinese CNKI, and WanFang databases to identify studies that assessed the association between clinicopathological feature and HSP27 expression in gastric cancer patients. Results. We found overexpression of HSP27 was associated with incidence of gastric cancer $(\mathrm{OR}=6.31,95 \% \mathrm{CI}=1.10-36.15, P<0.0001)$. However, there was no significant difference between HSP27 expression and gastric cancer differentiation, gender difference, lymph node metastasis, and distant metastasis. Conclusion. Our meta-analysis study indicates that overexpression of HSP27 is associated with incidence of gastric cancer statistically.
\end{abstract}

\section{Introduction}

Gastric cancer is the second leading cause of cancer-related mortality and the fourth most common cancer globally [1]. In 2014, 410,400 new stomach cancer cases and 293,800 cancer-associated deaths were estimated to have occurred in China. The crude incidence rate of stomach cancer was $30.00 / 100,000$, and the crude mortality rate of stomach cancer was 21.48/100,000 [2]. As many factors impact gastric cancer prognosis, identifying important biomarkers of gastric cancer will have a great influence for patients.

Small heat shock protein (sHSP) is a group of proteins, which express ubiquitously from prokaryotes to eukaryotes. HSP27 exists as a multimeric complex in the cells and serves functions, like refolding of unfolded proteins, regulation of cytoskeleton dynamics, and cell cycle regulation. sHSPs bind to a wide range of cellular proteins and are implicated in several cellular functions, apart from providing protection against various environmental and physical stressors, such as high temperature and chemical toxins [3].

High expression levels of HSP have been reported in many cancers, including breast, head and neck, gallbladder, colorectal, skin, liver, colon, renal, prostate, and ovarian cancer $[4,5]$. Of particular interest, HSPs play dual complex role in apoptosis via promoting or counteracting cell death. For instance, HSPs have been shown to activate apoptotic mediators such as procaspase 3 $[6,7]$, and conversely, they bind and inhibit several molecules at different levels in the apoptotic pathway [8]. The antiapoptotic events include the blockade of cytochrome $\mathrm{C}$ release from the mitochondria by HSP27 besides antagonizing caspase 3 and caspase 9 [9-11]. HSP27 can also suppress other apoptotic death receptor pathways, including TNF $\alpha$, Fas, and TRAIL [12].

HSP27 is reported to be a major target in combating cancer. An increased level of HSP27 is reported in different cancers, including breast cancer, endometrial cancer, and leukemia [3]. Although several studies have reported the relationship between HSP27 and gastric cancer, the conclusions are controversial and the patients included in each study are not enough. Therefore, we conducted meta-analysis of those studies to explore the relationship between HSP27 expression and clinicopathological feature of gastric cancer.

\section{Methods and Materials}

As there was a meta-analysis study published before about relationship between HSP27 expression and clinicopathological feature of gastric cancer, we referred to relevant content about method and material of the study [13]. 
2.1. Identification and Eligibility of Relevant Studies. We searched PubMed, Chinese CNKI, and WanFang databases to identify studies that assessed the association between clinicopathological feature and HSP27 expression in gastric cancer patients. The search ended in September 1, 2019. Search words were "heat shock protein 27," "HSP27," "gastric cancer," "gastric carcinoma," and "stomach neoplasm."

The included criteria for this study were as follows: (1) patients were diagnosed as gastric cancer; (2) HSP27 expression was tested in tissue of gastric patients by immunohistochemistry (IHC); (3) study design was case-control study or cross-sectional study; (4) studies included at least one primary outcome of interest; and (5) study was published in English or Chinese with full text available.

The excluded criteria for this study were as follows: (1) letters, reviews, conference abstracts, animal experiments, fundamental research, and duplicated studies were excluded; (2) studies that did not estimate the relationship of HSP27 expression and clinicopathological feature were excluded; and (3) studies whose data could not be used for metaanalysis were excluded.

2.2. Data Extraction. Two reviewers independently screened all studies to determine the relevant articles meeting the included criteria. Extracted data included the first author's name, publication year, sample size, country, and clinicopathologial features (HSP27 expression, gender, differentiation, lymph node metastasis, and distant metastasis). Disagreements were resolved by the third-party adjudication.

2.3. Quality Assessment. The quality of each included casecontrol study was assessed by the Newcastle-Ottawa scale (NOS), while the quality of cross-sectional study included was assessed by the Agency for Healthcare Research and Quality (AHRQ). Studies with NOS score $\geq 6$ were considered as good quality and with NOS score $<5$ were considered as poor quality. Studies with AHRQ score 8-11 were as good quality, with AHRQ score 4-7 were as moderate quality, and with AHRQ score $0-3$ were as poor quality.

2.4. Statistical Analysis. Review manager 5.3 software was used to perform the statistical analysis for these meta-analyses. Pooled odds ratios (ORs) with 95\% confidence intervals (CIs) were calculated to evaluate the association between HSP27 expression and clinicopathological feature. The heterogeneity was evaluated by the $I^{2}$ test. Fixed effects model was used when there was no significant heterogeneity $\left(I^{2}<50 \%, P \geq 0.1\right)$, while the random effect model was chosen if there was significant heterogeneity $\left(I^{2} \geq 50 \%, P<0,1\right)$.

\section{Results}

3.1. Eligible Studies. As shown in Figure 1, we identified 154 records from PubMed, CNKI, and WanFang databases. After excluding the duplicates and irrelevant studies, 25 studies remained to review the abstracts and full text to find available data. As some data in those studies could not be

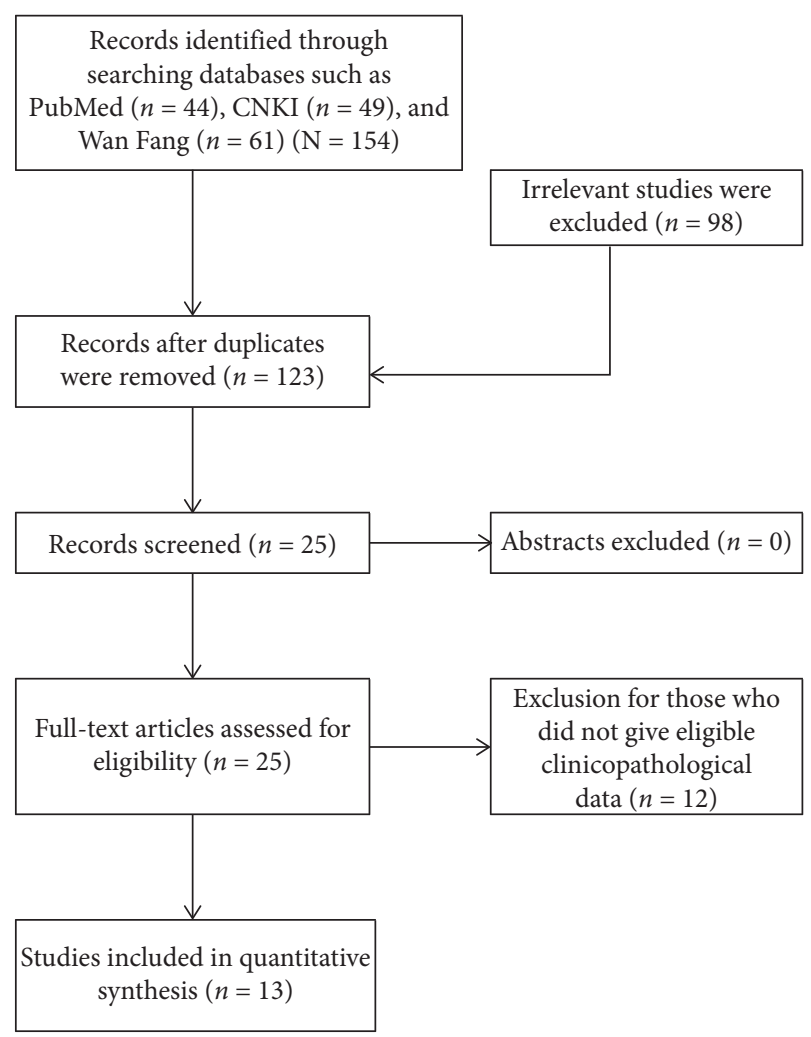

FIgURE 1: Flowchart of study selection.

used, finally, we got 13 studies to conduct meta-analysis to evaluate the relationship between HSP27 expression and clinicopathological feature [14-26].

The characteristics of included studies are shown in Table 1. We got 758 gastric patients, 256 paracancerous tissue specimens, and 230 normal tissue specimens. The included studies were published from 2001 to 2017 and conducted in different countries (ten in China, one in Jordan, one in Japan, and one in Greece). Based on NOS or AHRQ scores, 11 studies were evaluated as good quality, while 2 studies were as moderate quality.

3.2. Meta-Analysis. We extracted available data from included studies to conduct meta-analysis. As shown in Table 2 and Figure 2, we assessed the relationship between expression of HSP27 expression and clinicopathological feature of gastric cancer. We found overexpression of HSP27 was associated with incidence of gastric cancer $(\mathrm{OR}=6.31$, 95\% CI $=1.10-36.15, P<0.0001)$. However, there was no significant difference between HSP27 expression and gastric cancer differentiation $(\mathrm{OR}=1.14,95 \% \mathrm{CI}=0.52-2.52$, $P=0.74), \quad$ gender difference $\quad(\mathrm{OR}=0.95, \quad 95 \%$ $\mathrm{CI}=0.62-1.48)$, lymph node metastasis $(\mathrm{OR}=1.44,95 \%$ $\mathrm{CI}=0.66-3.16, P=0.36)$, and distant metastasis $(\mathrm{OR}=0.64$, $95 \% \mathrm{CI}=0.10-4.09, P=0.64)$.

3.3. Publication Bias. As shown in Figure 3, we used the funnel plot to assess the publication bias, and we found that there was no significant asymmetry about HSP27 expression in 


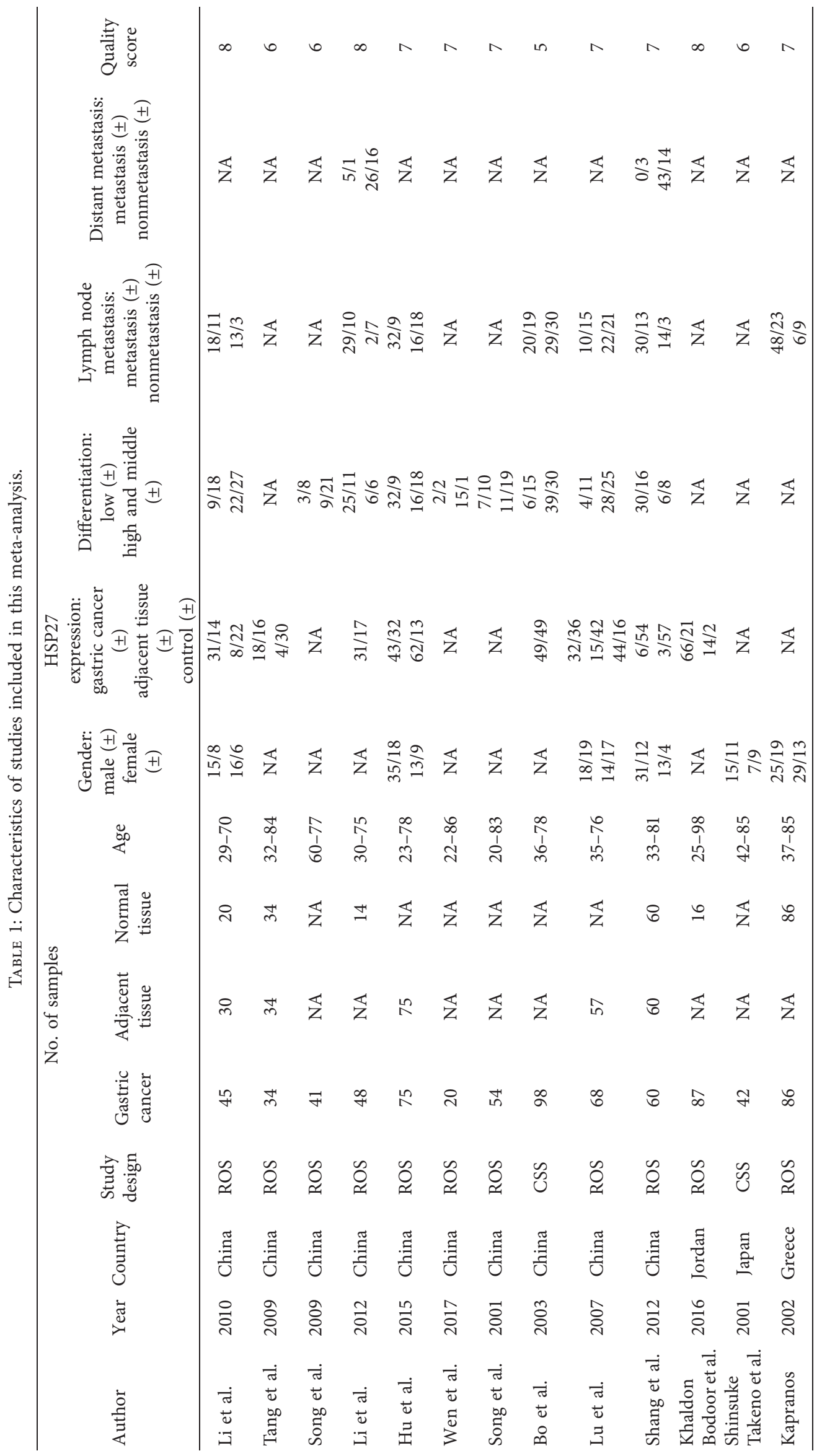


TABLE 2: The odds ratio between HSP27 expression and clinicopathological feature of gastric cancer.

Clinicopathological features

HSP27 expression

Differentiation

Gender

Lymph node metastasis

Distant metastasis

Abbreviations: GC, gastric cancer; AT, adjacent tissue; NT, normal tissue; PD, effect model; fixed, fixed effect model; OR, odds ratio; CI, conference interval.

\begin{tabular}{|c|c|c|c|c|c|c|c|c|c|c|}
\hline \multirow{3}{*}{$\begin{array}{l}\text { Study or subgroup } \\
\text { Li et al., } 2010\end{array}$} & \multicolumn{2}{|c|}{ Gastric cancer } & \multicolumn{2}{|c|}{ Adjacent tissue } & \multirow{3}{*}{$\begin{array}{c}\text { Weight } \\
(\%)\end{array}$} & \multirow{3}{*}{\multicolumn{2}{|c|}{$\begin{array}{c}\begin{array}{c}\text { Odds ratio } \\
\text { M-H, random, 95\% CI }\end{array} \\
6.09[2.18,16.99]\end{array}$}} & \multirow{2}{*}{\multicolumn{2}{|c|}{$\begin{array}{c}\text { Odds ratio } \\
\mathrm{M}-\mathrm{H} \text {, random, } 95 \% \mathrm{CI} \\
\end{array}$}} & \\
\hline & \multirow{2}{*}{$\frac{\text { Events }}{31}$} & \multirow{2}{*}{$\begin{array}{c}\text { Total } \\
45\end{array}$} & \multirow{2}{*}{$\begin{array}{c}\text { Events } \\
8\end{array}$} & \multirow{2}{*}{$\frac{\text { Total }}{30}$} & & & & & & \\
\hline & & & & & & & & & $\Longrightarrow$ & \\
\hline Lu et al., 2007 & 32 & 68 & 15 & 57 & 22.6 & $2.49[1.17,5.31]$ & & & $\longrightarrow$ & \\
\hline Shang et al., 2012 & 44 & 60 & 6 & 60 & 19.2 & $24.75[8.93,68.58]$ & & & $\longrightarrow$ & \\
\hline Tang et al., 2009 & 18 & 34 & 4 & 34 & 16.5 & $8.44[2.44,29.21]$ & & & -7 & \\
\hline Zhu et al., 2014 & 48 & 75 & 16 & 52 & 22.6 & $4.00[1.88,8.51]$ & & & $\multimap-$ & \\
\hline Total $(95 \%$ CI) & & 282 & & 233 & 100.0 & $6.25[2.88,13.57]$ & & & & \\
\hline Total events & 173 & & 49 & & & & & & & \\
\hline $\begin{array}{l}\text { Heterogeneity: tau } \\
\text { Test for overall effe }\end{array}$ & $\begin{array}{l}\mathrm{i}^{2}=13.7 \\
4(P<0.0\end{array}$ & $\begin{array}{l}f=4(P \\
b 1)\end{array}$ & $0.008) ; I^{2}$ & $1 \%$ & & & 0.01 & 0.1 & 10 & 100 \\
\hline & & & & & & & & Adjacent tissue & Gastric cancer & \\
\hline
\end{tabular}

(a)

\begin{tabular}{|c|c|c|c|c|c|c|c|c|c|c|}
\hline \multirow{3}{*}{$\begin{array}{l}\text { Study or subgroup } \\
\text { Khaldon Bodoor et al., } 2016\end{array}$} & \multicolumn{2}{|c|}{ Gastric cancer } & \multicolumn{2}{|c|}{ Control } & \multirow{2}{*}{$\begin{array}{c}\text { Weight } \\
(\%)\end{array}$} & \multirow{2}{*}{\multicolumn{2}{|c|}{$\begin{array}{c}\text { Odds ratio } \\
\mathrm{M}-\mathrm{H} \text {, random, } 95 \% \mathrm{CI}\end{array}$}} & \multirow{2}{*}{\multicolumn{2}{|c|}{$\begin{array}{c}\text { Odds ratio } \\
\mathrm{M}-\mathrm{H}, \text { random, } 95 \% \mathrm{CI}\end{array}$}} & \\
\hline & \multirow{2}{*}{$\begin{array}{c}\text { Events } \\
66\end{array}$} & \multirow{2}{*}{$\frac{\text { Total }}{87}$} & \multirow{2}{*}{$\frac{\text { Events }}{14}$} & \multirow{2}{*}{$\frac{\text { Total }}{16}$} & & & & & & \\
\hline & & & & & 23.7 & \multicolumn{2}{|l|}{$0.45[0.09,2.14]$} & \multirow{2}{*}{$\longrightarrow$} & - & \\
\hline Li et al., 2010 & 31 & 45 & 4 & 20 & 25.3 & $8.86[2.50,31.36]$ & & & 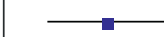 & \\
\hline Shang et al., 2012 & 44 & 60 & 3 & 60 & 25.2 & $52.25[14.32,190.64]$ & & & & \\
\hline Tang et al., 2009 & 18 & 34 & 5 & 34 & 25.8 & $6.53[2.04,20.89]$ & & & - & \\
\hline \multicolumn{2}{|l|}{ Total (95\% CI) } & 226 & & 130 & 100.0 & $6.31[1.10,36.15]$ & & & & \\
\hline & 159 & & 26 & & & & & & & \\
\hline \multirow{2}{*}{\multicolumn{5}{|c|}{$\begin{array}{l}\text { Heterogeneity: } \operatorname{tau}^{2}=2.71 ; \mathrm{chi}^{2}=21.29, \mathrm{~d} f=3(P<0.0001) ; I^{2}=86 \% \\
\text { Test for overall effect: } Z=2.07(P=0.04)\end{array}$}} & & & \multirow{2}{*}{0.005} & \multirow[t]{2}{*}{$\begin{array}{c}1 \\
0.1\end{array}$} & \multirow{2}{*}{$10 \begin{array}{c}10 \\
\text { Gastric cancer }\end{array}$} & 200 \\
\hline & & & & & & & & & & \\
\hline
\end{tabular}

(b)

\begin{tabular}{|c|c|c|c|c|c|c|c|c|c|c|}
\hline \multirow{3}{*}{$\begin{array}{l}\text { Study or subgroup } \\
\text { Bo et al., } 2003\end{array}$} & \multicolumn{2}{|c|}{$\mathrm{PD}$} & \multicolumn{2}{|c|}{ HMD } & \multirow{3}{*}{$\begin{array}{c}\begin{array}{c}\text { Weight } \\
(\%)\end{array} \\
12.9\end{array}$} & \multirow{2}{*}{$\begin{array}{c}\text { Odds ratio } \\
\mathrm{M}-\mathrm{H} \text {, random, } 95 \% \mathrm{CI}\end{array}$} & \multirow{2}{*}{\multicolumn{2}{|c|}{$\begin{array}{l}\text { Odds ratio } \\
\mathrm{M}-\mathrm{H}, \text { random, } 95 \% \mathrm{CI}\end{array}$}} & & \\
\hline & Events & Total & Events & Total & & & & & & \\
\hline & 6 & 21 & 39 & 69 & & \multicolumn{2}{|l|}{$0.31[0.11,0.89]$} & & & \\
\hline Li et al., 2010 & 22 & 27 & 9 & 18 & 11.3 & \multicolumn{2}{|l|}{$4.40[1.15,16.81]$} & & & \\
\hline Li et al., 2012 & 25 & 36 & 6 & 12 & 11.3 & \multicolumn{2}{|l|}{$2.27[0.60,8.64]$} & & & \\
\hline Lu et al., 2007 & 4 & 15 & 28 & 53 & 11.7 & \multicolumn{2}{|l|}{$0.32[0.09,1.15]$} & & & \\
\hline Shang et al., 2012 & 30 & 46 & 6 & 14 & 12.0 & \multicolumn{2}{|l|}{$2.50[0.74,8.47]$} & & & \\
\hline Song et al., 2001 & 7 & 17 & 11 & 30 & 12.0 & \multicolumn{2}{|l|}{$1.21[0.36,4.09]$} & & & \\
\hline Song et al., 2009 & 3 & 11 & 9 & 30 & 10.2 & \multicolumn{2}{|l|}{$0.88[0.19,4.08]$} & & & \\
\hline Wen et al., 2017 & 2 & 4 & 15 & 16 & 5.4 & \multicolumn{2}{|l|}{$0.07[0.00,1.12]$} & - & & \\
\hline Zhu et al., 2014 & 32 & 41 & 16 & 34 & 13.2 & \multicolumn{2}{|l|}{$4.00[1.47,10.88]$} & & - & \\
\hline Total $(95 \%$ CI) & & 218 & & 276 & 100.0 & \multicolumn{2}{|l|}{$1.14[0.52,2.52]$} & & & \\
\hline Total events & 131 & & 139 & & & & & & & \\
\hline \multicolumn{7}{|c|}{ Heterogeneity: $\operatorname{tau}^{2}=0.98 ;$ chi $^{2}=26.08, \mathrm{~d} f=8(P=0.001) ; I^{2}=69 \%$} & 1 & 1 & 1 & 1 \\
\hline \multicolumn{7}{|c|}{ Test for overall effect: $Z=0.33(P=0.74)$} & 0.005 & 0.1 & 10 & 200 \\
\hline
\end{tabular}

(c)

Figure 2: Continued. 


\begin{tabular}{|c|c|c|c|c|c|c|c|c|c|}
\hline \multirow{3}{*}{$\begin{array}{l}\text { Study or subgroup } \\
\text { Li et al., } 2010\end{array}$} & \multicolumn{2}{|c|}{ Male } & \multicolumn{2}{|c|}{ Female } & \multirow{3}{*}{$\begin{array}{c}\text { Weight } \\
(\%)\end{array}$} & \multirow{2}{*}{$\begin{array}{c}\text { Odds ratio } \\
\text { M-H, fixed, } 95 \% \text { CI }\end{array}$} & \multirow{2}{*}{\multicolumn{2}{|c|}{$\begin{array}{c}\text { Odds ratio } \\
\text { M-H, fixed, } 95 \% \text { CI }\end{array}$}} & \\
\hline & \multirow{2}{*}{$\frac{\text { Events }}{15}$} & \multirow{2}{*}{$\frac{\text { Total }}{23}$} & \multirow{2}{*}{$\frac{\text { Events }}{16}$} & \multirow{2}{*}{$\frac{\text { Total }}{22}$} & & & & & \\
\hline & & & & & & $0.70[0.20,2.51]$ & & & \\
\hline Lu et al., 2007 & 18 & 37 & 14 & 31 & 18.9 & $1.15[0.44,3.00]$ & & & \\
\hline N.Kapranos, 2002 & 25 & 44 & 29 & 42 & 30.9 & $0.59[0.24,1.43]$ & & & \\
\hline Shang et al., 2012 & 31 & 43 & 13 & 17 & 12.6 & $0.79[0.22,2.93]$ & & & \\
\hline Shinsuke Takeno et al., 2001 & 15 & 26 & 7 & 16 & 8.8 & $1.75[0.50,6.16]$ & & & \\
\hline Zhu et al., 2014 & 35 & 53 & 13 & 22 & 15.1 & $1.35[0.48,3.74]$ & & & \\
\hline Total (95\% CI) & & 226 & & 150 & 100.0 & $0.95[0.62,1.48]$ & & & \\
\hline Total events & 139 & & 92 & & & & & & \\
\hline $\begin{array}{l}\text { Heterogeneity: } \text { chi }^{2}=2.91, \mathrm{~d} \\
\text { Test for overall effect: } Z=0.2\end{array}$ & $\begin{array}{l}(P=0.7 \\
=0.83)\end{array}$ & $I^{2}=0$ & & & & 0.01 & 0.1 & 10 & 100 \\
\hline
\end{tabular}

(d)

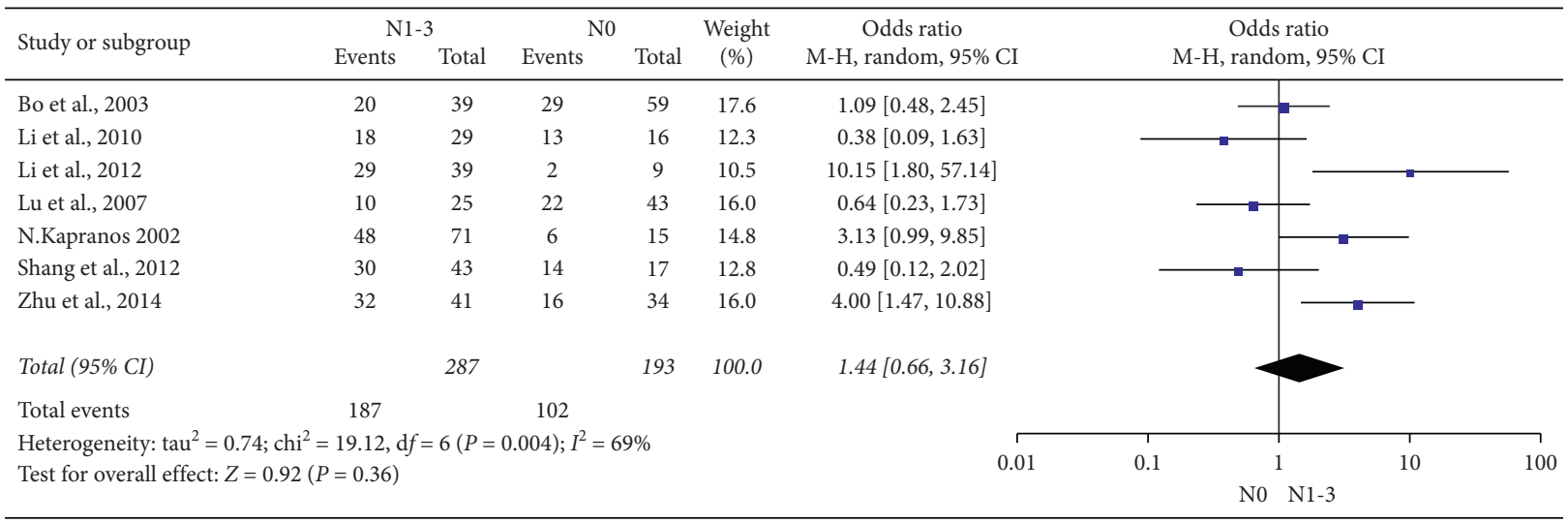

(e)

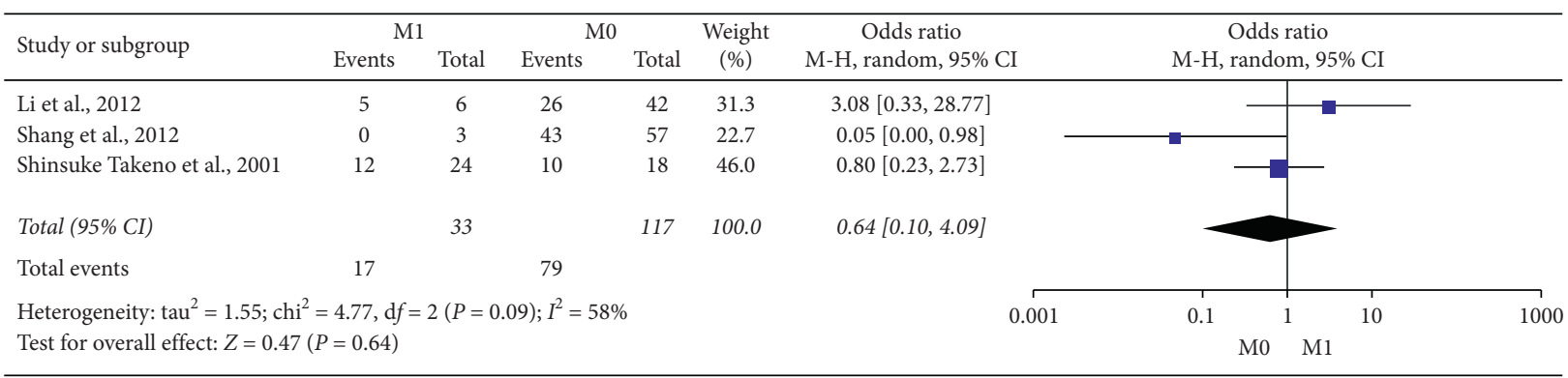

(f)

FIGURE 2: Forest plot of literatures including assessing the relationship between HSP27 expression and clinicopathological features: (a) GC vs AT; (b) GC vs NT; (c) PD vs HMD; (d) male vs female; (e) N1-3 vs N0; (f) M1 vs M0. Abbreviations: GC, gastric cancer; AT, adjacent tissue; NT, normal tissue; PD, poor differentiation; HMD, high or moderate differentiation; random, random effect model; fixed, fixed effect model; OR, odds ratio; and CI, conference interval.

comparison between gastric cancer and normal tissue, male and female, lymph node metastasis and nonlymph node metastasis, and distant metastasis and nondistant metastasis.

\section{Discussion}

We compared our results with previous meta-analysis of the association between HSP27 expression and clinicopathological feature of gastric cancer, which included 9 articles [13]. In our study, we included 13 articles to extract more available data to conduct meta-analysis. Although we added 4 more articles in this meta-analysis based on previous study, we finally got similar results as before. There was statistical significance between overexpression of HSP27 and incidence of gastric cancer. However, we still did not find significance of HSP27 expression in gastric cancer differentiation, genders, lymph node, and distant metastasis.

Previous meta-analysis study combined normal tissue and gastric carcinoma adjacent tissue as the control group. However, considering the difference between normal tissue and gastric carcinoma adjacent tissue, we compared the gastric carcinoma with normal tissue or gastric carcinoma adjacent tissue, respectively. To our surprise, we found there was publication bias in comparison between gastric cancer and its adjacent tissue. The reason might be the different way of choosing and punching biopsy.

As a protein chaperone, HSP27 had many functions in cell, such as antiapoptosis and protecting cell. There were several 


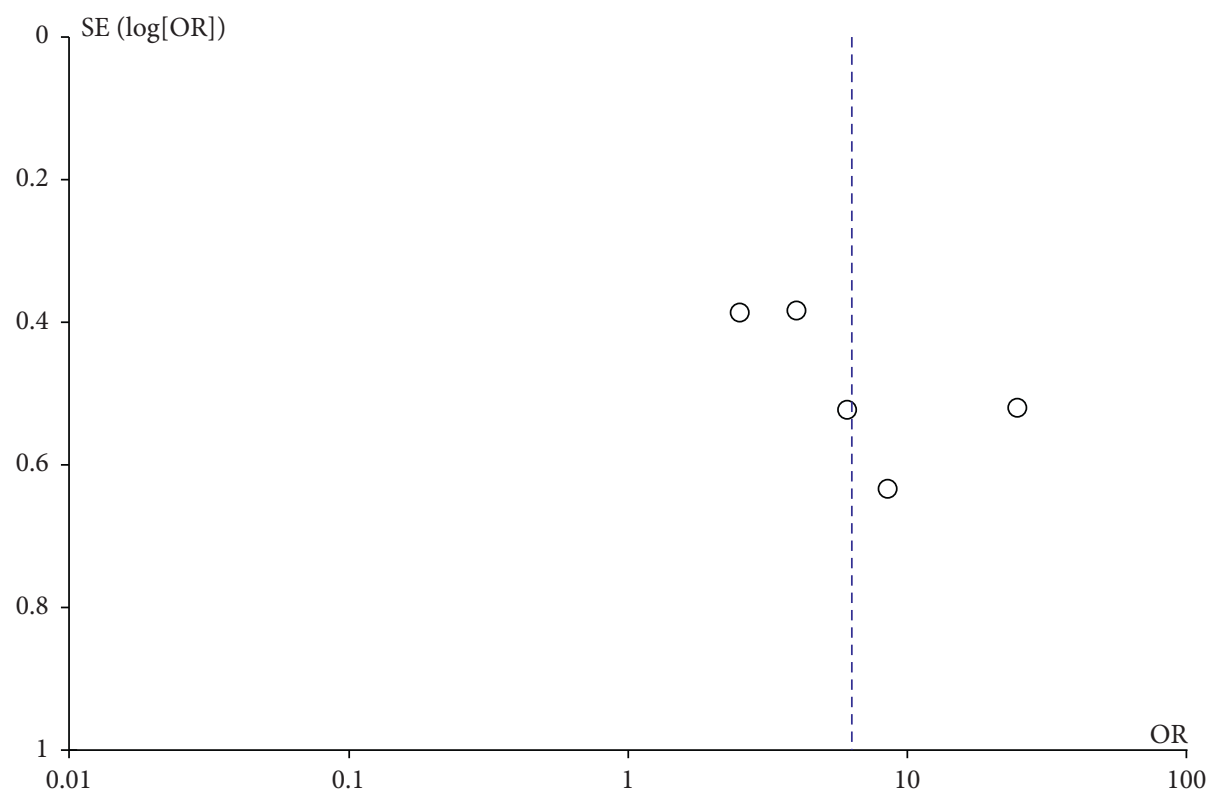

(a)

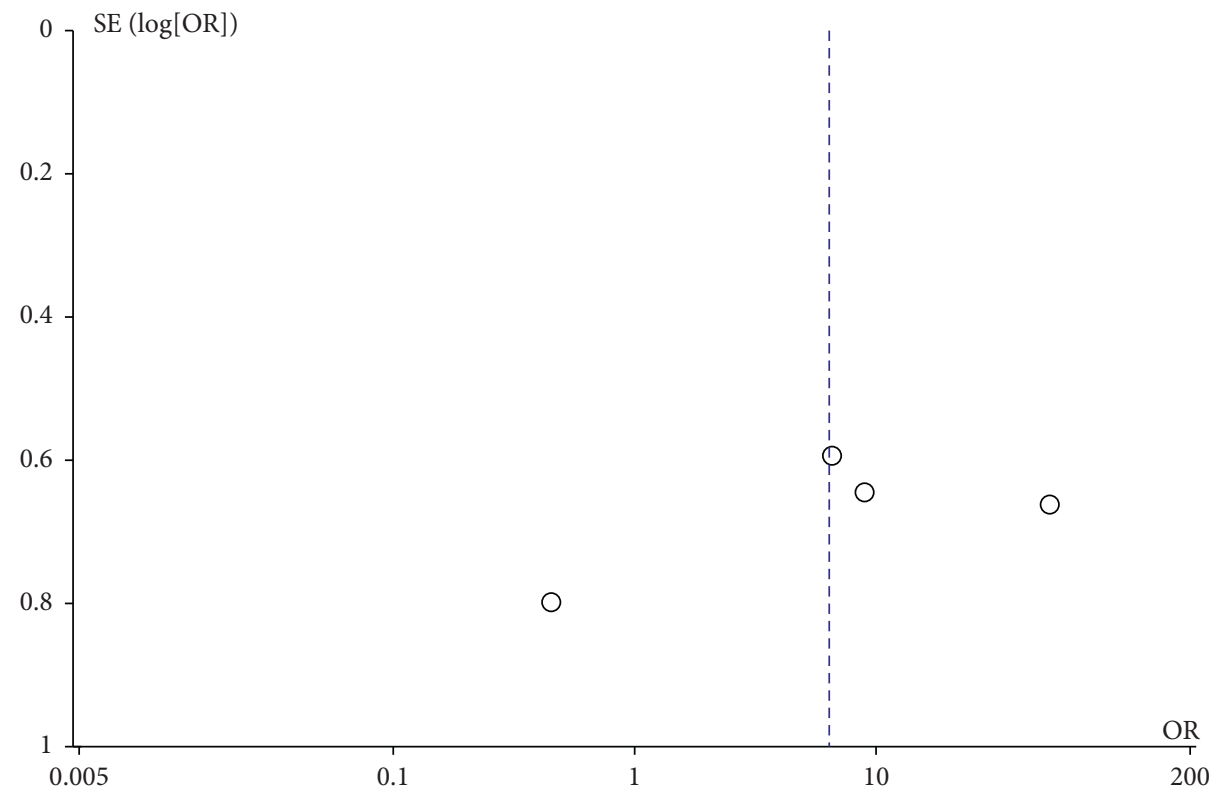

(b)

FIgURE 3: Continued. 


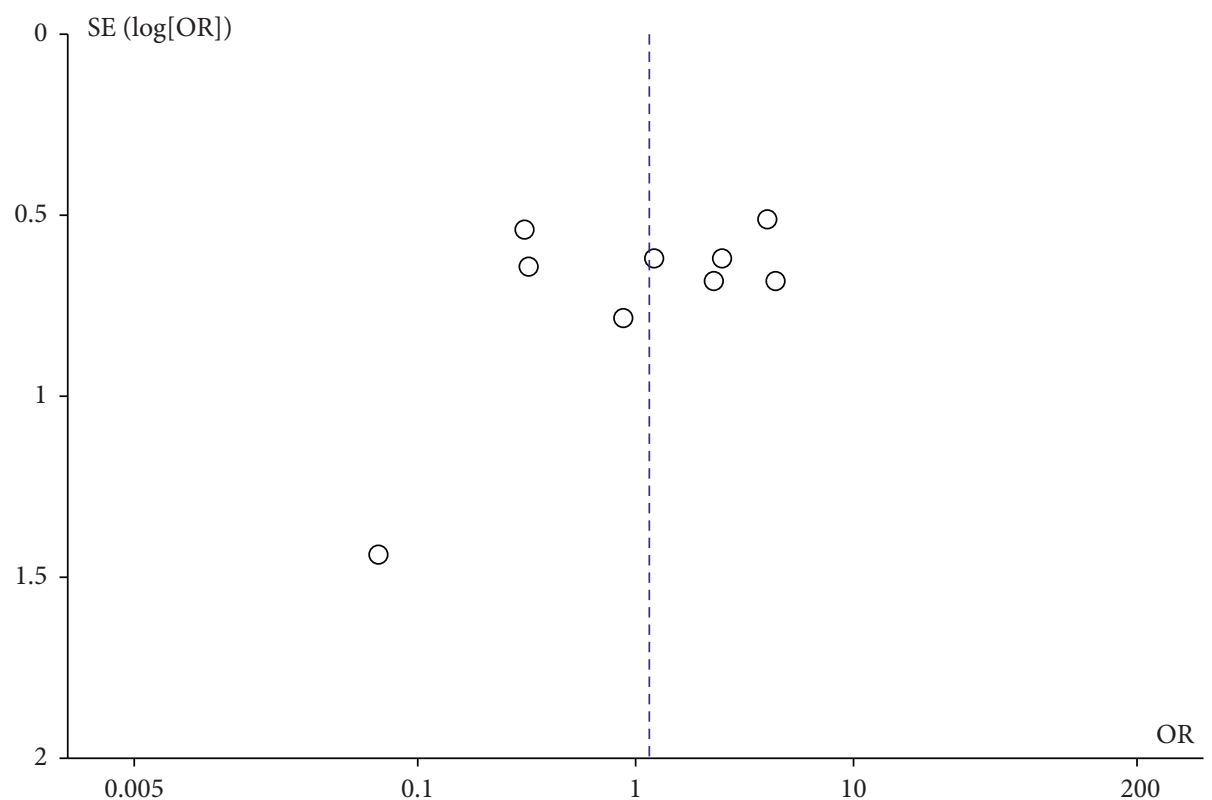

(c)

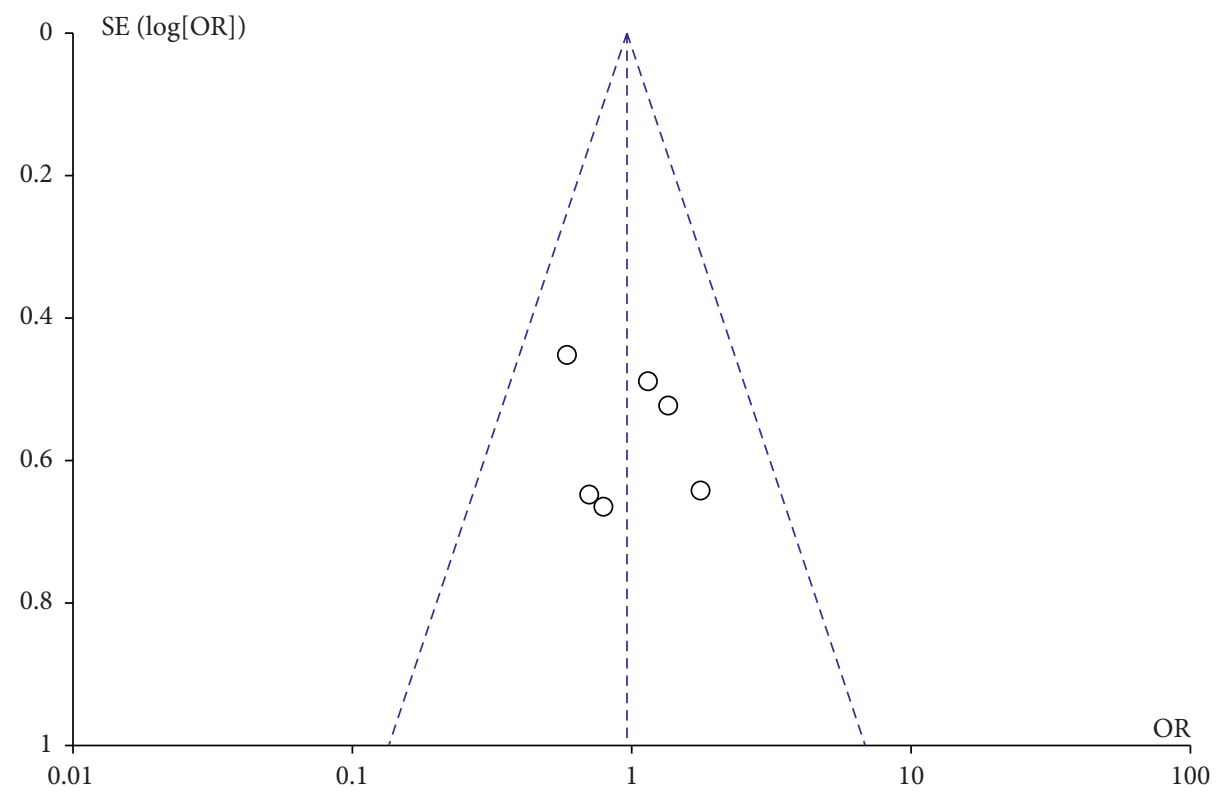

(d)

Figure 3: Continued. 


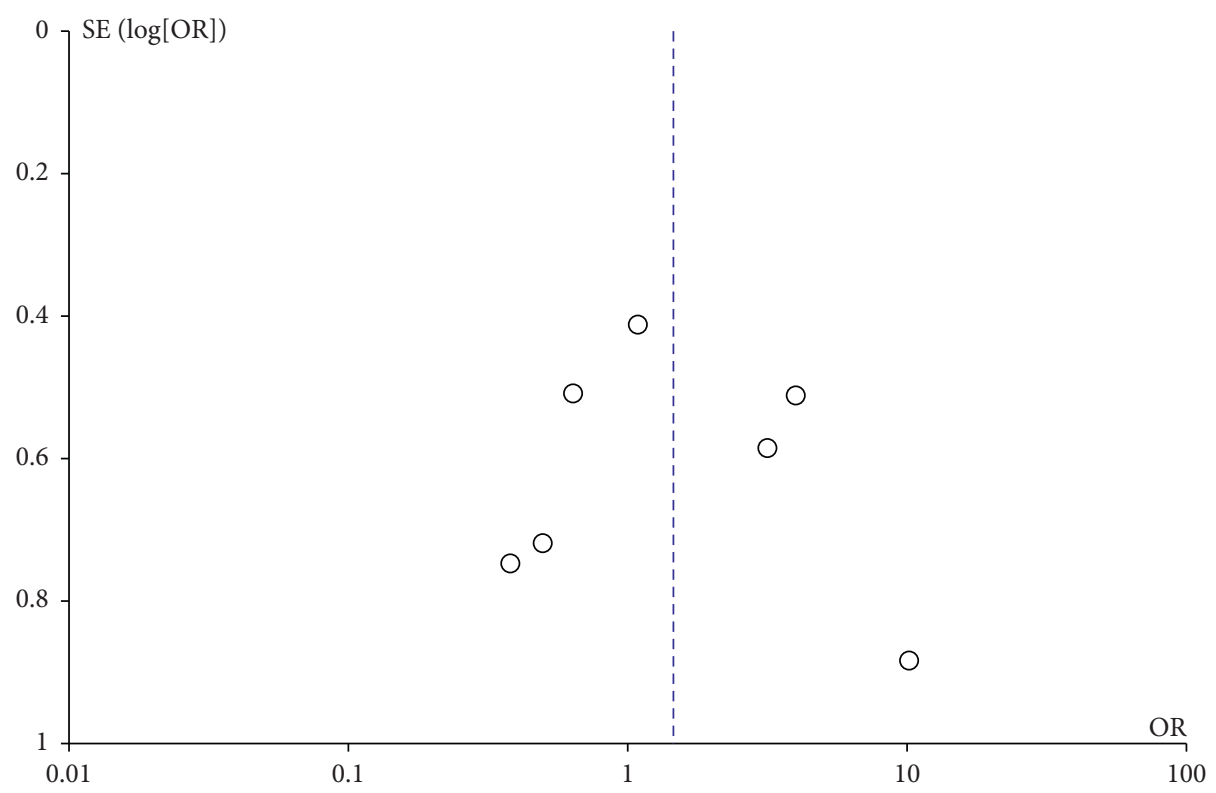

(e)

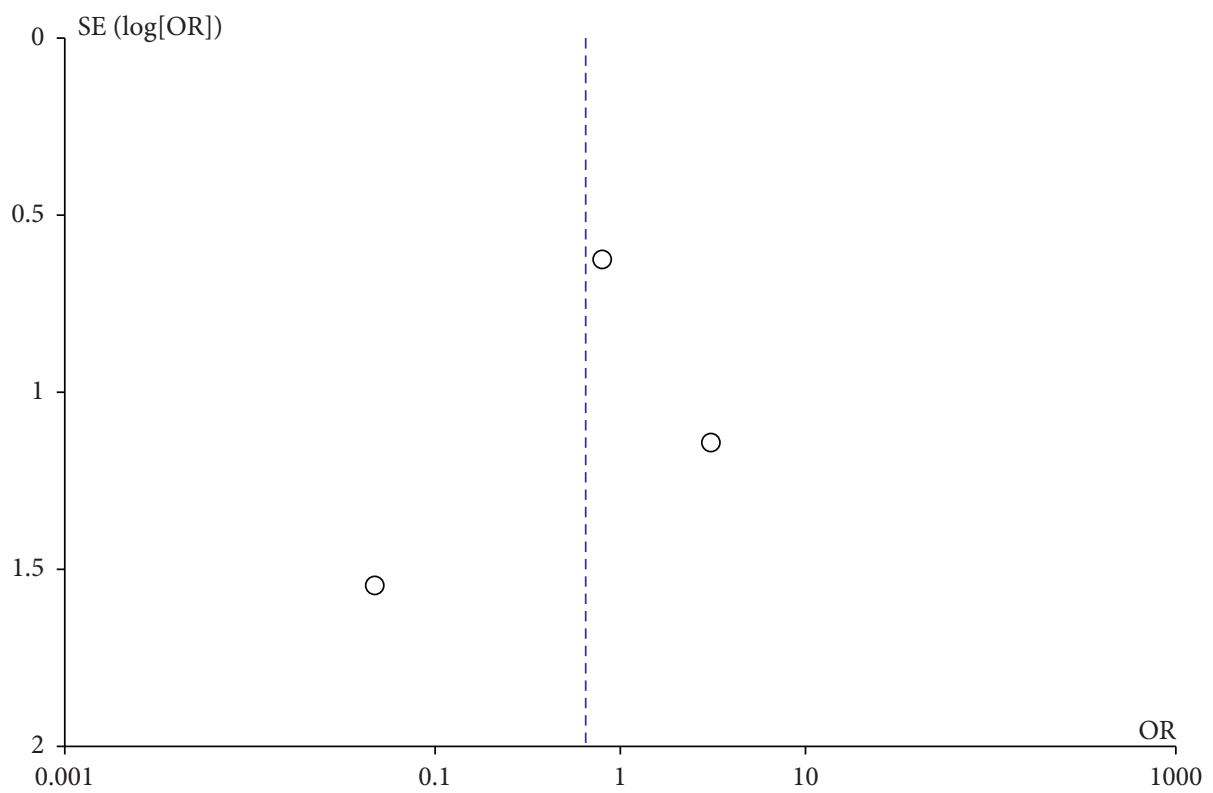

(f)

FIGURE 3: Funnel plot of literatures including assessing the relationship between HSP27 expression and clinicopathological features: (a) GC vs AT; (b) GC vs NT; (c) PD vs HMD; (d) male vs female; (e) N1-3 vs N0; (f) M1 vs M0. Abbreviations: GC, gastric cancer; AT, adjacent tissue; NT, normal tissue; PD, poor differentiation; HMD, high or moderate differentiation; random, random effect model; fixed, fixed effect model; OR, odds ratio; and CI, conference interval.

reports indicating that HSP27 was upregulated in many cancers. Some studies even suggested HSP27 was associated with poor prognosis and was drug resistant, as it could protect tumor cell from apoptosis induced by drugs [27]. In summary, HSP27 might play an important role in cancer therapy and become a new target for treatment in the future.

\section{Conclusion}

Our meta-analysis study indicates that overexpression of HSP27 is associated with incidence of gastric cancer statistically. However, more high-quality research studies with a large sample size should be conducted in future.

\section{Conflicts of Interest}

The authors declare that they have no conflicts of interest.

\section{References}

[1] T. L. Ang and K. M. Fock, "Clinical epidemiology of gastric cancer," Singapore Medical Journal, vol. 55, no. 12, pp. 621-628, 2014. 
[2] L. Yang, R. Zheng, N. Wang et al., "Incidence and mortality of stomach cancer in China, 2014," Chinese Journal of Cancer Research, vol. 30, no. 3, pp. 291-298, 2018.

[3] M. K. Singh, B. Sharma, and P. K. Tiwari, "The small heat shock protein Hsp27: Present understanding and future prospects," Journal of Thermal Biology, vol. 69, pp. 149-154, 2017.

[4] S. Chatterjee and T. Burns, "Targeting heat shock proteins in cancer: A promising therapeutic approach," International Journal of Molecular Sciences, vol. 18, no. 9, p. 1978, 2017.

[5] G. Jego, A. Hazoumé, R. Seigneuric, and C. Garrido, "Targeting heat shock proteins in cancer," Cancer Letters, vol. 332, no. 2, pp. 275-285, 2013.

[6] A. Samali, J. Cai, B. Zhivotovsky, D. P. Jones, and S. Orrenius, "Presence of a pre-apoptotic complex of pro-caspase-3, Hsp60 and Hsp10 in the mitochondrial fraction of Jurkat cells," The EMBO Journal, vol. 18, no. 8, pp. 2040-2048, 1999.

[7] S. Xanthoudakis, S. Roy, D. Rasper et al., "Hsp60 accelerates the maturation of pro-caspase- 3 by upstream activator proteases during apoptosis," The EMBO Journal, vol. 18, no. 8, pp. 2049-2056, 1999.

[8] D. Kennedy, R. Jäger, D. D. Mosser, and A. Samali, "Regulation of apoptosis by heat shock proteins," IUBMB Life, vol. 66, no. 5, pp. 327-338, 2014.

[9] S. K. Calderwood and J. Gong, "Heat shock proteins promote cancer: It's a protection racket," Trends in Biochemical Sciences, vol. 41, no. 4, pp. 311-323, 2016.

[10] D. Chauhan, G. Li, T. Hideshima et al., "Hsp27 inhibits release of mitochondrial protein Smac in multiple myeloma cells and confers dexamethasone resistance," Blood, vol. 102, no. 9, pp. 3379-3386, 2003.

[11] C. Garrido, M. Brunet, C. Didelot, Y. Zermati, E. Schmitt, and G. Kroemer, "Heat shock proteins 27 and 70: Anti-apoptotic proteins with tumorigenic properties," Cell Cycle, vol. 5, no. 22, pp. 2592-2601, 2006.

[12] A.-P. Arrigo and B. Gibert, "HspB1 dynamic phospho-oligomeric structure dependent interactome as cancer therapeutic target," Current Molecular Medicine, vol. 12, no. 9, pp. 1151-1163, 2012.

[13] H. Ge, X. He, L. Guo, and X. Yang, "Clinicopathological significance of HSP27 in gastric cancer: a meta-analysis," OncoTargets and Therapy, vol. 10, pp. 4543-4551, 2017.

[14] G. X. Li, P. Li, Z. M. Yang et al., "Expression and clinical significance of HSP27 and Survivin in gastric carcinoma," Shaanxi Medical Journal, vol. 39, no. 1, pp. 93-96, 2010.

[15] D. Tang, S. W. Tang, Z. W. Luo et al., "The expression of heatshock protein 27 in gastric cancer," Tumor, vol. 29, no. 3, pp. 272-275, 2009.

[16] G. J. Song, D. Cuishi, and B. Aihua, "Expression of heat shock protein 27 and glutathione S-transferase in gastrointestinal cancer," Chinese Journal of Gerontology, vol. 29, no. 5, pp. 616-617, 2009.

[17] G. Q. Li and J. R. Zhao, "Expression and significance of heat shock protein 27/60 in gastric cancer," Chinese Journal of Gastroenterology, vol. 21, no. 1, pp. 31-33, 2012.

[18] F. L. Hu, Q. Y. He, X. P. Li et al., "Expression and clinical significance of P-cadherin and HSP27 proteins in gastric carcinoma," Acta Universitatis Medicinalis Nanjing, vol. 35, no. 1, pp. 26-30, 2015.

[19] W. Jin, N. Fang, H. Deng et al., "Expression and significance of heat shock protein 27 in gastric carcinoma," Jiangxi Medical Journal, vol. 52, no. 3, pp. 198-203, 2017.

[20] G. J. Song, D. Cuishi, G. S. Wang et al., "Studys on expression of heat shock protein in the alimentary canal cancer of human," Journal of Zhangjiakou Medical College, vol. 18, no. 1, pp. 39-40, 2001.

[21] B. O. Aihua, D. S. Zuo, X. Zhang et al., "Expression of HSP27 and TopoII in gastric cancer," Chinese Journal of Cancer, vol. 22, no. 8, pp. 884-885, 2003.

[22] A. Q Lu, Z. S. Qin, and S. Y. Lei, "Expression and significance of heat shock protein 27 in gastric carcinoma," Journal of Snake, vol. 19, no. 2, pp. 108-110, 2007.

[23] J. C. Shang, Y. K. Qu, and W. X. Liu, "Expression and significance of HSP27, 70 and 90 in gastric cancer," World Health Digest Medical Periodieal, vol. 9, no. 24, pp. 445-448, 2012.

[24] K. Bodoor, S. Abu Jalboush, I. Matalka et al., "Heat shock protein association with clinico-pathological characteristics of gastric cancer in Jordan:HSP70 is predictive of poor prognosis," Asian Pacific Journal of Cancer Prevention, vol. 17, pp. 3929-3937, 2016.

[25] S. Takeno, T. Noguchi, R. Kikuchi et al., "Analysis of the survival period in resectable stage IV gastric cancer," Annals of Surgical Oncology, vol. 8, no. 3, pp. 215-221, 2001.

[26] N. Kapranos, A. Kominea, P. Konstantinopoulos et al., "Expression of the $27-\mathrm{kDa}$ heat shock protein (HSP27) in gastric carcinomas and adjacent normal, metaplastic, and dysplastic gastric mucosa, and its prognostic significance," Journal of Cancer Research and Clinical Oncology, vol. 128, no. 8, pp. 426-432, 2002.

[27] S.-Ki Choi, H. Kam, K.-Y. Kim, S. I. Park, and Y.-S. Lee, "Targeting heat shock protein 27 in cancer: A druggable target for cancer treatment?" Cancers, vol. 11, no. 8, p. 1195, 2019. 